fourth-and fifth-year pupils in 1987 did not get worse when compared to a similar group in 1989. However, those of cigarette smoking did. That may be partly a function of the absence of a prevention programme since there is already good evidence to suggest that anti-smoking education campaigns have a better success rate (Health Education Authority, 1987). On the other hand, major increases occurred between 1987 and 1989 within the follow-up population, suggesting that there may be a place for prevention programmes at an earlier age.

This follow-up, despite its limitations, is among the few that have been carried out in this country. It may represent the situation among London adolescents, but we cannot tell if it represents all UK adolescents, underlying the need for further nationwide surveys monitoring trends and allowing for better planning and provision of services for adolescent and adult substance misusers. After all, addicts most often start drug use in adolescence.

\section{References}

HeALTH EDUCATION AUtHORTTY (1987) Smoking Education for Teenagers Project. London: HEA.

NewCOMB, R. \& O'HARE, P. (1988) A Survey of Drug Use among Young People in South Sefton in 1987. South Sefton Health Authority.

Swadi, H. (1988) Drug and substance use among a population of 3,333 London adolescents. British Journal of Addiction, 83, 935-942.

-(1989) Epidemiological Aspects of Substance Misuse in a Population of London Adolescents. (M.Phil Dissertation). London University.

\title{
'Lillian' - a play on schizophrenia
}

\author{
SURINDER S. JoHL, Senior Psychiatrist, Launceston General Hospital, Launceston, \\ Tasmania, Australia
}

"Welcome to 'Lillian'. This is all about schizophrenia. Schizophrenia is an illness, a serious mental illness which affects one person in a hundred. It is an illness which causes strange thoughts and strange feelings. It leads to emotional disturbances and a withdrawal from the reality of the external world. Those who suffer from it withdraw into their own world, into an unreal world of fantasy. Often they are tormented by strange and frightening experiences. Some develop strange ideas and fear that they are persecuted. Others hear voices, see and feel things that are not there, though they are real to them. Sometimes it is difficult to understand them because their thoughts are jumbled. They may even feel that someone else is interfering with their minds. In time, some lose their ability to do their everyday activities and lose their drive and initiative but this is not laziness. They often become very anxious and have periods of depression. For many the ability to express their emotions is blunted and in others their behaviour is unusual. These experiences are all very real to them and sadly some never realise what is happening to them. Most do recover with treatment, understanding and support but often under stress, relapses occur. We ask for your understanding and support".

These were the opening statements of a play put on by the patients and staff of the Department of Psychiatry, of Launceston General Hospital, Launceston, a relatively small conservative city of 65,000 in Northern Tasmania. The results made history. It was the first full-length theatre production in the form of a rock musical on mental illness.

The idea sprang in the Day Centre when some patients expressed the wish and need of making the public aware of mental illness, and the special needs of the mentally ill. They were aware of the stigma they faced following admission to the local psychiatric unit and the difficulties thereafter. This was taken up by our occupational therapist, Michael Bishop, who had experience in directing and producing plays. He took the bold step of booking the theatre almost nine months ahead. A drama group was set up with interested patients and they related in their own words their experiences starting from the time their problems started, their admissions to hospital, and events thereafter. Many had been through bitter experiences as a result of their illness and had much to say. A theme developed and a story began.

Lillian is a 19-year-old college student working in a news-agency. She develops schizophrenia, is admitted to hospital, recovers with treatment and relapses when she experiments with cannabis, an all too 
familiar story. During her illness Lillian views her parents and the psychiatric staff as cold, unfeeling and bound by rules and convention. Her parents lack warmth, understanding, support and strongly deny her illness as she is tormented by her symptoms. Her boyfriend never tries to understand and, in fact, introduces her to cannabis. In contrast her brother, Sam, plays a leading role in providing the support she needs. Some problems that were current at the time of the writing of the play were included, for example, the contribution of evangelism to her excessive religiosity while ill.

The first draft of the script took three months to complete, and, in the meantime, the enormous task of raising funds to stage the production began. Our first raffle raised a tiny amount and promises for funds from some sources never materialised. But undeterred, it led to countless raffles, lamington drives, cake-stalls, a dance-a-thon, a fashion show, a garage sale, busking and numerous donations, small and large, often from unexpected sources. As an awareness for the project grew, help in the form of technical support and expertise was offered from sources too numerous to mention.

At the auditions parts were offered to interested patients, staff and students, many with no previous experience. Anna Waters, the lead singer with Boo Boo Gazoo, a local rock group, was offered the leading role of Lillian, and a drama teacher, the role of Sam, her brother. Together with Anna Waters came her group who provided the original music. Anna wrote six original catchy tunes, "Support's The Only Way", "Don't Shut Me Out", "What's Happening To Me", "Our Daughter's In A Loony Bin", "Sam", and "When We Were Young" for the play. As the rehearsals and momentum developed, a make-up artist and his team offered to provide their services, as did a choreography teacher and numerous others. Soon the cast grew to over 40 , including eight life-sized puppets who represented Lillian's hallucinations.

The play was brilliantly directed and co-ordinated by Michael Bishop and received enormous support from all the staff of the Department who dedicated much time and effort to get the show on stage. In the cast there were 11 patients and ex-patients, some with chronic schizophrenia who played major roles in the play. For many their previous listless, colourless lives began to change through the new relationships they developed. They found themselves talking about new things to their friends and families as their confidence and self-esteem increased in this new environment. As the rehearsals became more frequent and demanding, many required increased support and counselling. For patients participating in the project it was immensely therapeutic, and video playbacks of the rehearsals provided an excellent feedback of their performance. Some, who were shocked by their appearance made determined efforts to make changes. Throughout the preparations the main aim of increasing awareness of schizophrenia to the community was never forgotten. The hospital provided the services of their publicity officer as well as materials for the play. Sets were made at a rehabilitative work-preparation unit, and the cast diligently undertook to paint them. There were newspaper articles, radio and television interviews, as well as free advertising by the local television station. All this attracted much interest in the play and in mental illness. Letters of support were received from all over the country. Prominent artists and politicians, including the Prime Minister, expressed support for the project and this helped boost confidence.

The tickets were priced cheaply so that the cost would not be a barrier to watching the play. Together with the tickets, pamphlets on schizophrenia and mental illness were distributed so that they would be read and the play understood better.

Numerous problems developed, the cost of the sound system led to a budget blow-out, an acutely ill patient threatened to talk about her own views on schizophrenia on stage, and a whole lot of minor problems occurred. On 8 September 1989, the day of the premier staging of the play, there was much tension and apprehension that something unexpected might occur. The theatre was packed on both nights, quite an unexpected response as the theatre had not been at full capacity for years. The performance went smoothly and the audience responded positively to the music, humour, sadness and conflicts faced by Lillian. The music and lyrics reflected on the pain, lack of understanding and support from her family and friends. An outstanding choreographic feature was a ballet of puppets representing the hallucinations of Lillian. During the show the puppets also made their appearance among the audience, enhancing the hallucinatory effects. There was humour in parts, emphasising the not uncommon ignorance about mental illness. Lillian's brother, Sam, narrated the events in between scenes, which included her interview with the psychiatrist, the ward community meeting, the party where she was introduced to cannabis, and her re-admission. The play climaxed with a song and dance, "Support's The Only Way", and a standing ovation.

The show achieved a high level of professionalism and provided a powerful message on schizophrenia in both a serious and entertaining way. The next step would be to publish it and make it available more widely. 